\title{
Penetrating Marjolin's ulcer of scalp involving bone, dura mater and brain caused by blunt trauma to the burned area
}

\author{
G. Sengul and H. Hadi-Kadioglu
}

Department of Neurosurgery. Medical School. Ataturk University. Erzurum. Turkey.

\section{Summary}

Marjolin's ulcer, which was first described more than 1.5 centuries ago, involves a rare malignant transformation of chronic scar tissue or ulcer. Marjolin's ulcer invading the skull, dura mater and the brain is quite exceptional. A case is presented of a patient with a massive Marjolin's ulcer arising in chronic scarring of the scalp following a fire burn 57 years previously. The tumour had invaded the skull, dura mater and the brain. The patient was treated surgically but died after 20 days. This report aims to highlight the importance of appropriate and expeditious initial wound management of scar ulcers of the scalp.

KEY WORDS: Brain. Marjolin's ulcer. Scalp. Squamous cell carcinoma.

Úlcera penetrante de Marjolin, que afecta al hueso, duramadre y cerebro, causada por un golpe romo en una cicatriz de quemadura.

\section{Resumen}

La úlcera de Marjolin, que se describió por vez primera hace más de siglo y medio, se refiere a la rara transformación maligna de una vieja cicatriz o de una úlcera crónica. La úlcera de Marjolin, que invada el cráneo y el cerebro es bastante excepcional. Se presenta el caso de un paciente con una extensa úlcera de Marjolin, que aparece en una cicatriz secundaria a una quemadura ocurrida 50 años antes. El tumor había invadido el cráneo, la duramadre y el cerebro. Se enfermo murió 20 días después de la intervención quirúrgica. Este trabajo tiene como fin destacar la importancia de un tratamiento, rápido y apropiado, de las cicatrices ulceradas del cuero cabelludo.

PALABRAS CLAVE: Cerebro. Ulcera de Marjolin. Cuero

Recibido: 10-09-08. Aceptado: 15-12-08 cabelludo. Carcinoma células escamosas.

Introduction

Marjolin's ulcer is a well-recognized long-term malignant complication of burn scars and other chronically irritating local skin conditions. It tends to develop over atrophic, unstable burn scars many years after the burn injury has occurred $^{1-5}$. Though it is known as a plastic surgical problem, when it invades the dura and brain it becomes of neurosurgical interest.

\section{Case Report}

A 64-year-old male was admitted to our clinic with a 6 weeks history of an ulcerative lesion arising from the scalp and with increasing left-sided weakness. His past medical history revealed that he had had a flame burn due to dropping in an oven ("tandir") when he was 7 years old. He had been treated with dressings at home by his local medical practitioner. The wound had been closed by scarring during a period of months. The area had remained unchanged until he hit his head on the branch of a tree about 57 years later, resulting in an ulcerating lesion in the previous scar, $2 \mathrm{~cm}$ in diameter, to the right of the midline at the cranial vertex. He had applied topical henna on the wound to treat it. There had been repeated episodes of serosanguinous discharge from the ulcer. The ulcer had continued to increase in size, and a cauliflower-like granulomatous mass had appeared in the center of the ulcerated and defected lesion in which many larvae were reproducing.

On examination, he was conscious, vital signs were stable and he had a $3 / 5$ left hemiparesis. He had a $15 \times 15 \mathrm{~cm}$ fungating growth over the vertex with its center ulcerated. The surface was covered with soft, yellowish-grey necrotic material with intervening hemorrhagic areas (Figure 1). The margins of the ulcer were irregular and indurated. Calvarial skull defect was seen in the ulcer. Interestingly, dura mater was also involved and the cerebral tissue could be seen through the defect. Within the lesion many live larvae. No regional lymph node enlargement was 


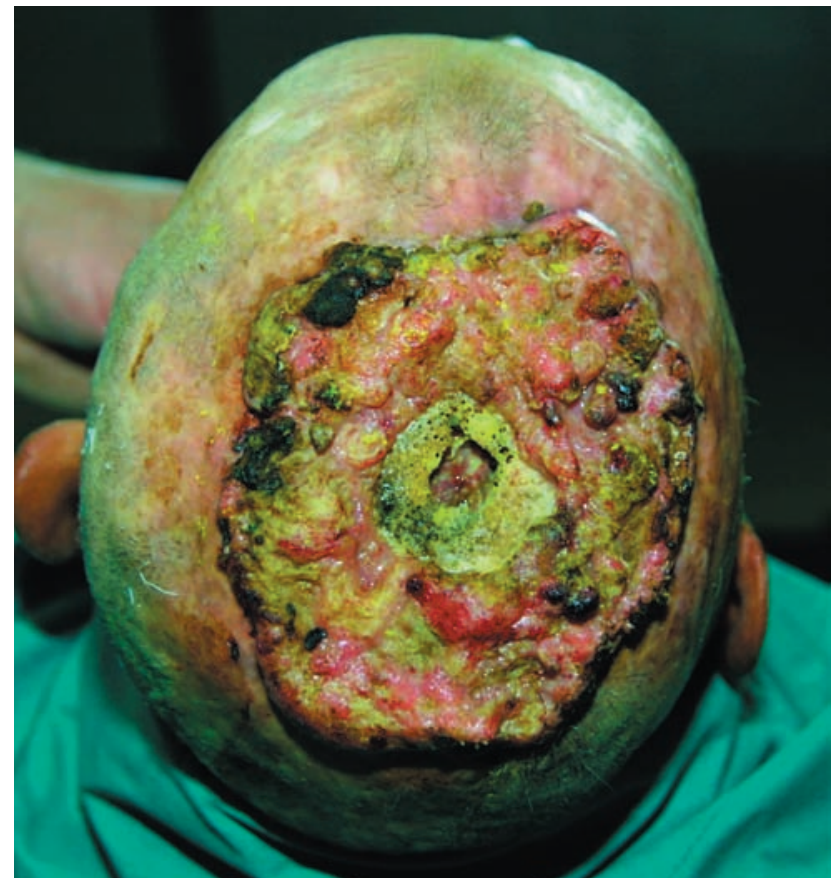

Figure 1. Pre-operative photograph showing the ulceration on the vertex of the scalp - view is from the top of the head with the patient lying down.

observed. Microscopy and culture of the necrotic areas revealed gram negative cocci and appropriate antibiotics were administered and continued after the surgery. Plain X-ray of the skull demonstrated a skull defect with rarefaction of the surrounding bone. A computed tomography (CT) scan confirmed the destruction of bone and showed multiple extradural collections and meningeal thickening (Figure 2). The patient underwent operation under general anesthesia. At surgery, the affected area was cleaned with saline solution and the larvae were removed. The ulcerated growth was excised with a $2 \mathrm{~cm}$ margin of normal skin and the unhealthy bone margins were nibbled away. The dura was infiltrated and adherent to the underlying brain. The superior sagittal sinus was obliterated. The involved dura and an area of abnormal cortical brain tissue were excised and the dural defect was repaired using a fascia lata graft. Postoperative CT scan showed clearing of the extradural collection with right parietal craniectomy defect (Figure 3). The patient was next referred to plastic surgery department for reconstruction of the scalp. Twenty days after reconstruction operation he died at home. The cause of death could not be determined. Histopathology of the fungating lesion revealed squamous cell carcinoma with invasion of calvarial bone and brain (Figure 4).

\section{Discussion}

Marjolin's ulcers are rare tumours that originate in

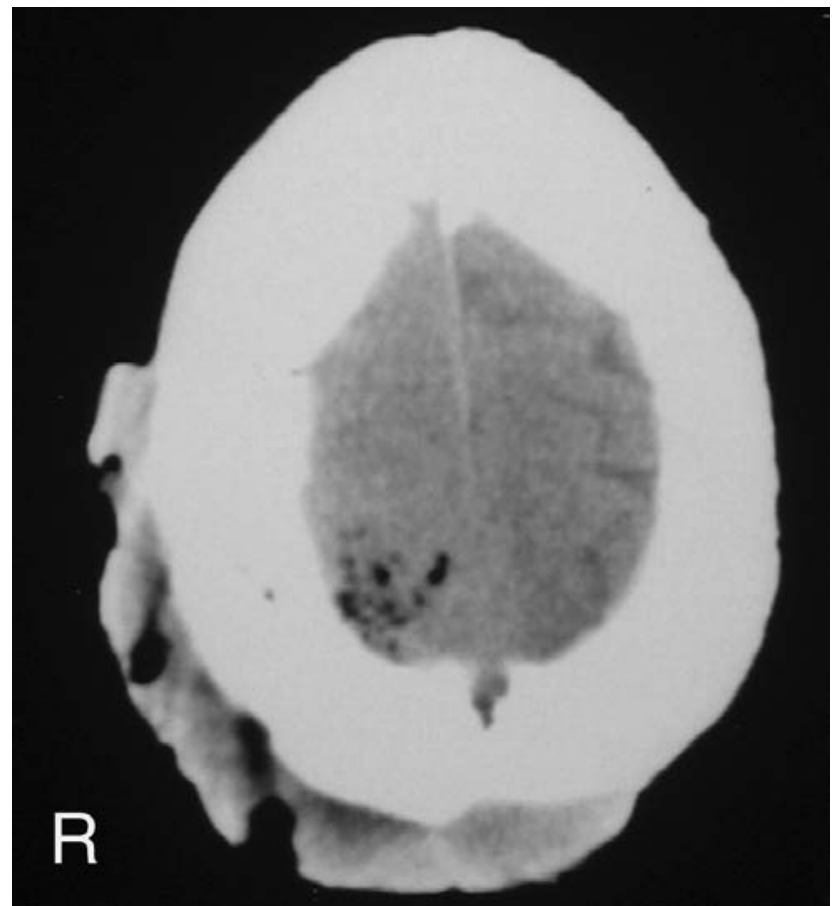

Figure 2. CT scan showing the destruction of bone, multiple extradural collections and meningeal thickening.

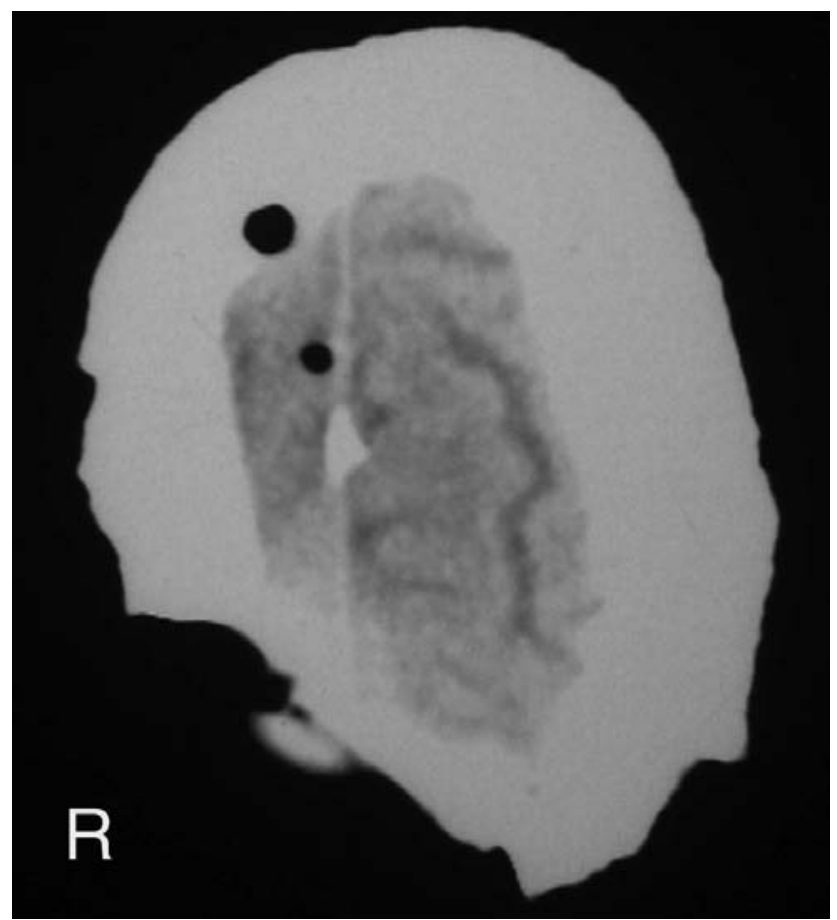

Figure 3. Postoperative CT scan showing clearing of the extradural collection with right parietal craniectomy defect.

chronically inflamed skin. Marjolin originally described the malignant degeneration of cutaneous scars in $1828^{4,9,10}$. Although it was described originally in a burn scar, it can 


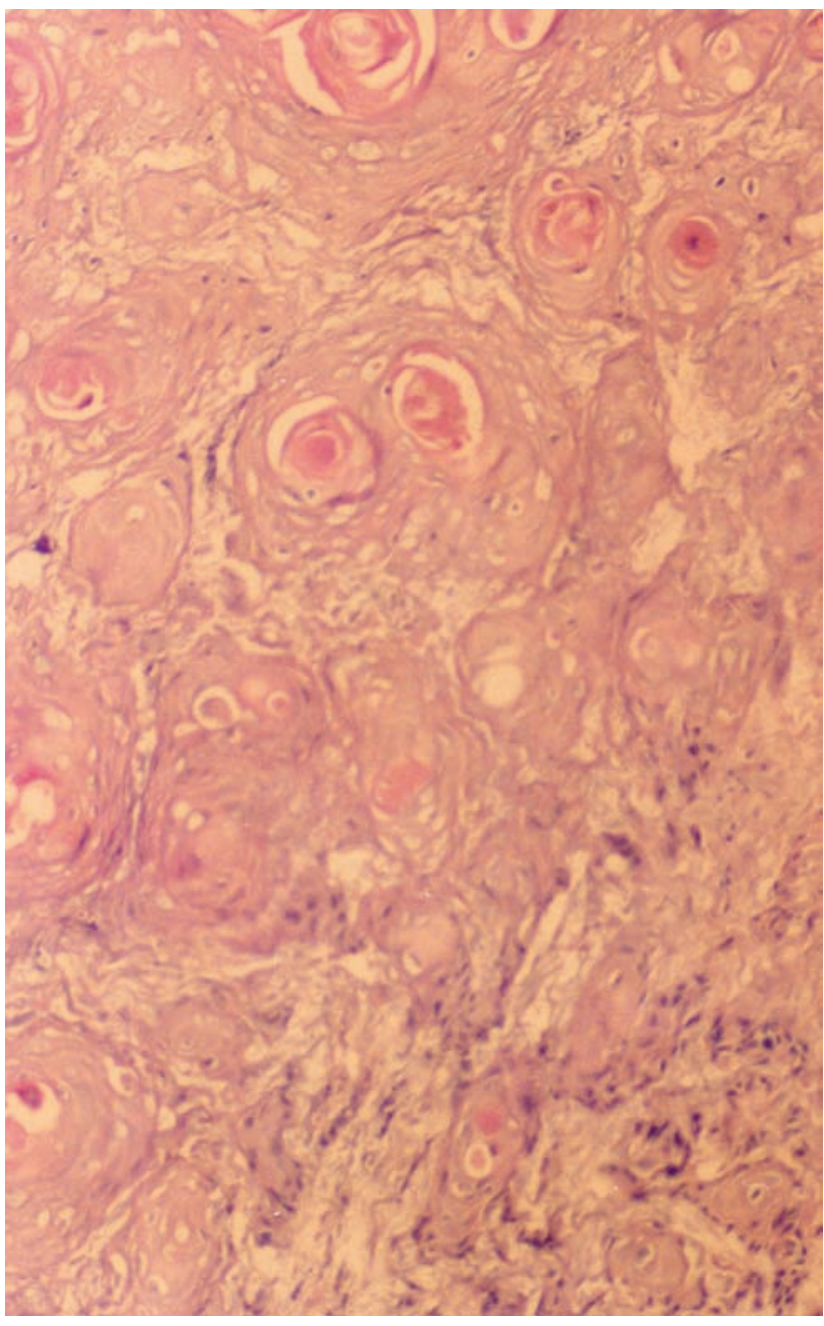

Figure 4. Photomicrograph showing invasive squamous cell carcinoma of the scalp.

arise in any chronic wound. The mechanisms of malignant change is supposed to be a sequence of repeated ulceration and healing in the ulcers and osteomyelitic sinuses and of repeated trauma in scars. Some proposed mechanisms include a carcinogenic toxin produced from the burned tissue, the cicatricial tissue which prevents the action of the immune system on the new tumour formation, and finally a two-step process involving an initiator and promoter leading to cancer ${ }^{2,4,9,10}$. We believe that trauma is the most important initiating factor in the pathogenesis of the Marjolin's ulcer as in our case. Anyway, many cases reported in the literature are secondary to the trauma to the burned area.

Most burn scar carcinomas are of squamous cell type as in our case, however basal cell carcinoma, adenocarcinoma, malignant melanoma and mesenchymal malignancy have been documented ${ }^{2-4,6,9,11}$.

All parts of the body can be affected by this malignancy, but extremities, trunk and scalp are the most frequently involved. As the scalp is well vascularized, there is in this location a lower incidence of Marjolin's ulcer when compared to the other sites. Invasion of the skull, dura mater and the brain is quite exceptional and has only been reported in a limited number of $\operatorname{cases}^{1,2,7-9}$.

Two variants of Marjolin's ulcer have been described; an acute form, in which the cancer occurs within one year of the injury and a chronic form in which malignant changes are more than one year from the date of injury ${ }^{2,7}$. The average latency in chronic form is 36 years, and in our case was longer. Another striking feature of our case was the rapid tumour progression after trauma to the burned area not only in the scalp but also in the neighboring structures and brain parenchyma.

Marjolin's ulcer can be a very aggressive tumour that necessitate a well thought out treatment plan to optimize care and assure patient survival ${ }^{3}$. Early diagnosis and prompt surgical intervention is mandatory in Marjolin's ulcers of the scalp as they may invade vital structures. Wide surgical excision and radiotherapy have been proposed for treatment. Reconstructive techniques are useful ${ }^{3,7,10}$. The effect of radiotherapy is controversial because of the poor vascular supply of the tumor and there is not too much information about this issue in the literature. On the other hand, there is no consensus for regional lymph node dissection. Dissection is recommended only when lymph nodes are clinically palpable. The optimum treatment for advanced Marjolin's ulcer remains controversial. We think that palliative surgical interventions must be considered in advanced cases due to their low cure possibility as well was in our case.

Recurrence and fatality rates are higher due to the aggressive nature of this tumour ${ }^{1,4,7}$. Most important prognostic factors are histopathological type, grade of lesion and presence of metastasis at the time of diagnosis. Reviewing the literature, prognosis was generally poor in patients with Marjolin's ulcer of the scalp invading the brain.

In conclusion, appropriate and expeditious initial wound management of scar ulcers will facilitate wound healing and minimize the risks of malignant transformation.

\section{References}

1. Akoz, T., Erdoğan, B., Gorgu, M., Aslan, G.: The necessity for aggressive treatment with Marjolin's ulcers of the scalp. Plast Reconstr Surg 1997; 100: 805-806.

2. Aydogdu, E., Yildirim, S., Akoz, T.: Is surgery an effective and adequate treatment in advanced Marjolin's ulcer? Burns 2005; 31: 421-431.

3. Calikapan, G.T., Akan, M., Karaca, M., Aköz, T.: Marjolin ulcer of the scalp: intruder of a burn scar. J Craniofac 
Surg 2008; 19: 1020-1025.

4. Copcu, E., Aktas, A., Sişman, N., Oztan, Y.: Thirty-one cases of Marjolin's ulcer. Clin Exp Dermatol 2003; 28: 138141.

5. Copcu, E., Sivrioglu, N., Baytekin, C., Koc, B., Er, S.: Very acute and aggressive form of Marjolin's ulcer caused by single blunt trauma to the burned area. J Burn Care Rehabil 2005; 26: 459-460.

6. Gan, B.S., Colcleugh, R.G., Scilley, C.G., Craig, I.D.: Melanoma arising in a chronic (Marjolin's) ulcer. J Am Acad Dermatol 1995; 32: 1058-1059.

7. Gupta, S.K., Sandhir, R.K., Jaiswal, A.K., Kumar, S.: Marjolin's ulcer of the scalp invading calvarial bone, dura and brain. J Clin Neurosci 2005; 12: 693-696.

8. Maillard, G.F., Landolt, A.: Penetrating Marjolin's ulcer of scalp involving bone and dura mater treated by wide excision and direct application of a split-skin graft on the brain: a 10-year follow-up. Br J Plast Surg 1984; 37: 463-467.

\section{Comment on the article Penetrating Marjolin's ulcer of scalp involving bone, dura mater and brain caused by blunt trauma to the burned area, by Goksin Sengul et al.}

The article "Penetrating Marjolin's ulcer of scalp involving bone, dura mater and brain caused by blunt trauma to the burned area" presents an unusual case of Marjolin's ulcer in the scalp with cranial bone and brain invasion. Reports on Marjolin's ulcers in neurosurgical literature are limited because diagnosis and treatment of this pathology is more specific to specialities such as plastic surgery. However, some cases which need a multidisciplinary approach can demand neurosurgical attention, like the one described in this article. On the other hand, this kind of tumour is extremely rare in industrialized countries where medical assistance makes possible an early and appropriate treatment of complicated wounds, reducing the potential of becoming malignant. In addition to its rarity, we think this is an interesting case because its diagnosis and treatment raise issues still unresolved.
9. Ozek, C., Celik, N., Bilkay, U., Akalin, T., Erdem, O., Cagdas, A.: Marjolin's ulcer of the scalp: report of 5 cases and review of the literature. J Burn Care Rehabil 2001; 22: 65-69.

10. Ozek, C., Cankayali, R., Bilkay, U., Guner, U., Gundogan, H., Songur, E., Akin, Y., Cagdas, A.: Marjolin's ulcers arising in burn scars. J Burn Care Rehabil 2001; 22: 384-389.

11. Ozyazgan, I., Kontas, O.: Basal cell carcinoma arising from surgical scars: a case and review of the literature. Dermatol Surg 1999; 25: 965-968.

Sengul, G.: Hadi-Kadioglu, H.: Penetrating Marjolin's ulcer of scalp involving bone, dura mater and brain caused by blunt trauma to the burned area. Neurocirugía 2009. 20 . 474-477.

Correspondence to: Goksin Sengul, MD. Ataturk University, Medical School, Department of Neurosurgery, Aziziye Research Hospital, 25070-Yenisehir, Erzurum, Turkey.
In the article, no mention is made on some details like the need of performing a study of tumoral extension in the patient or planning adjuvant radiotherapy/chemotherapy, despite being an advanced case. The influence on prognosis of that adjuvant treatments, and also regional lymph node dissection, is not well established. Overall, a regional relapse rate after surgery of $58 \%$, an incidence rate of metastasis of $35 \%$, and a 5 -year survival rate of $52 \%$ have been reported (Aydogdu et al. Reference 2). Faced with this bad prognosis, we agree with the authors when they highlight the importance of a right wound management in cases of skin burns or chronic ulcers in order to reduce the risk for malignant transformation. This preventive strategy is the best way to treat Marjolin's ulcers. 